Így hivatkozzon erre a cikkre:

Futó Péter. „Szociális informatika az MSzT konferenciáján”. Információs Társadalom VII, 1. szám (2007): 109-113.

A folyóiratban közölt müvek

a Creative Commons Nevezd meg! - Ne add el! - Így add tovább! 4.0 
Futó Péter

\section{Szociális informatika az MSzT konferenciáján}

A Magyar Szociológiai Társaság 2006. évi konferenciáján (Budapest, 2006. november 10-11.) a harmadik szekciót a szociális informatikának szentelték. Az egész délutánt kitöltố szekcióülésnek átlagosan 15-20 látogatója volt, akik összesen hat elôadást hallgattak és vitattak meg angol nyelven.

A szekció angol címe elnclusion volt: ez a viszonylag új szakterület a leszakadással és kirekesztốdéssel fenyegetett társadalmi csoportoknak a digitális technológiák segítségével történố felzárkóztatását és az erre irányuló szakpolitikát öleli fel. Az elnclusion programok elsốdleges célcsoportjai a fogyatékkal élók, az idősek, a kisebbségek, a bevándorlók és más olyan speciális lakossági csoportok, amelyeknek a társadalomba ezen belül különösen az információs társadalomba - történó integrálása kívánatos lenne. A szekció egyik előadása például az idős és beteg családtagjaikat ápoló személyekról szólt, pontosabban arról, hogy miként segíthetnek a digitális technológiák e speciális élethelyzetû - eredeti szándékuk ellenére ápolóvá vált - személyeknek.

Az eInclusion olyan kérdésekkel foglalkozik, hogy milyen jogi, intézményi és múszaki eszközökkel lehet elérhetôvé, hozzáférhetôvé tenni e célcsoportok részére a digitális tartalmakat, speciálisan a digitálisan közvetített egészségügyi, oktatási, államigazgatási és üzleti szolgáltatásokat, hogyan kell terjeszteni a digitális technikákhoz való hozzáértést, és miként javíthatók ezeknek a csoportoknak a foglalkoztatottsági mutatói.

A téma aktualitását az adja, hogy az Európai Unió minisztereinek 2006-os Rigai Nyilatkozata azt a célt tûzte ki, hogy 2010-ig földrészünkön felére kell csökkenteni a digitális technológiák használatában fennálló társadalmi különbségeket, az ún. digitális szakadékot.

A szekció elsó elôadása az elnclusion politikai programok hatásainak nyomon követéséról, az ún. monitoring tevékenységrốl szólt. ${ }^{1}$

Indulásként a német kutatóhelyról érkezett előadó bemutatta az „eInclusion@EU” elnevezésû projektet, amelyen belül a monitoring lehetôségek felvázolása az egyik részfeladat volt. Maga a projekt nem kutatási jellegú, hanem az EU úgynevezett koordinációs akciója, amelyet három éven keresztül az úgynevezett FP6 kutatási-fejlesztési keretból finanszíroznak. Ez azt jelenti, hogy a nemzetközi projekt résztvevoói először az egyes országokban (D, IRL, B, CH, I, DK, UK, FI, HU) élő levelező partnerek segítségével - Európa 27 országában felmérik az eInclusion terén folyó programokat és tevékenységeket, valamint az ezzel kapcsolatos jogszabályokat, intézményeket és fórumokat, továbbá a kérdéssel foglalkozó szakértóket és egyéb érdekelteket. Ezzel párhuzamosan összegyújtik az információs technológiákhoz való hozzáférésre, az isme-

\footnotetext{
${ }^{1}$ Monitoring eInclusion in Europe. Szerzók: Ingo Meyer, Sonja Müller és Lutz Kubitschke, empirica Gescllschaft für Kommunikations- und Technologieforschung GmbH, Bonn, Németország.
} 
retükre és használatukra vonatkozó hivatalos statisztikákat, felmérési eredményeket és forrásmunkákat. Az egyes adatgyújtési akciók fó témakörei: a digitális technikákhoz való hozzáférés, a digitális technikák és a munka világa, és végül az elektronikus szolgáltatások.

Az adatgyújtést követôen a keletkezố adat- és tudásbázist rendezik, és közzéteszik egy szakmai hálózati honlapon. Ezután - többek között e honlap segítségével is ösztönzik az érdekeltek párbeszédét, és munkaértekezleteket szerveznek. Végül a projekt egyik fontos feladata, hogy a résztvevók politikai javaslatokat fogalmaznak meg az Unió, valamint az egyes tagállamok döntéshozói számára.

Az előadás a fentiekben vázolt széles körú nemzetközi anyaggyưjtés alapján számba vette a leginkább fenyegetô digitális szakadékokat, a 25 EU tagországban megvalósuló eInclusion intézkedések eszközrendszerét, és tételesen kitért arra, hogy az intézkedések megvalósítását és hatásukat milyen módon követhetik nyomon a döntéshozók.

Az európai országokban rendszeres idóközönként szerveznek olyan konferenciákat, amelyek kvalitatív áttekintést adnak az eInclusion politikai programok aktuális helyzetéról. Ennél valamivel ritkábban indítanak az érdekeltek megkérdezésére irányuló, kvantitatív információkat is szolgáltató kérdőíves felméréseket. Ez az oka annak, hogy míg jelenleg meglehetôsen jó áttekintéssel rendelkezünk magukról az intézkedésekrốl, addig a hatásukról csak vázlatos és hézagos elképzelésünk lehet. Nyitott kutatási feladat tehát, hogy mely országokban mely lakossági csoportokat fenyegeti leginkább leszakadással a rohamosan terjedő digitális technika, ez milyen mechanizmusok útján érvényesül, és a véges mennyiségben rendelkezésre álló közösségi, valamint magánerôforrásokat hogyan kellene optimális, célzott módon bevetni e fenyegetések elhárítására.

A szekciómásodik elóadása az „eInclusion@EU” projekt azon eredményeit mutatta be, melyek a digitális tartalmak hozzáférhetốségének szabályozására vonatkoznak. ${ }^{2}$

Az írországi kutatóhely eredményeit részletezô prezentáció azt részletezte, hogy az európai országokban milyen jogi és intézményi kereteket alakítottak ki abból a célból, hogy a hálózati honlapokat, a digitális televíziót és más digitális technikai eszközöket hozzáférhetôvé tegyék a fogyatékkal élő és az idôsebb személyek számára. Ebben a szövegkörnyezetben a hozzáférhetôség fogalmára új angol szót szerkesztettek: az ezredforduló óta az Európai Unió Bizottsága úgy tekinti, hogy az úgynevezett eAccessibility nemcsak szociális és etikai, hanem politikai követelményeket is állít a döntéshozók elé, illetve ilyen kötelezettségeket is ró rájuk.

A fogyatékkal élő és az idősebb személyekkel való szolidaritást a digitális hozzáférhetôség területén több uniós szintû döntés és jogszabályok egész sora fejezi ki, amelyek a közösségi honlapok hozzáférhetôségét, a távközlési szolgáltatók által kötelezóen biztosítandó minimális szolgáltatásokat, továbbá a szerzói jog kötelmei alól való felmentés, a közbeszerzés és a foglalkoztatási esélyegyenlőség területeit szabályozzák a veszélyeztetett lakossági csoportok érdekében.

\footnotetext{
${ }^{2}$ Policies to achicve eAccessibility in Europe. Szerzók: Kevin Cullen és Ivica Milicevic, Work Research Centre, Dublin, Írország.
} 
A szekció harmadik elóadása a fogyatékos személyeknek az európai és az amerikai információs társadalomba történó beilleszkedésével, az erre vonatkozó politikai és kutatási tevékenységek fejlődéséról szólt. ${ }^{3}$

Az EU munkavégzố korban lévő (16 és 64 év közötti) állampolgárainak 14 és fél százaléka kénytelen valamilyen testi vagy szellemi fogyatékosságával együtt élni. Ennek a jelentôs társadalmi csoportnak csak 42 százaléka áll alkalmazásban, míg a nem fogyatékos személyek körében a foglalkoztatási arány 65 százalékos. Becslések szerint az EU-ban mintegy 60 és 80 millió között lehet azoknak a személyeknek a száma, akik fogyatékkal élnek vagy idôsek.

Az esélyegyenlőséghez való jogot 1997-ben az Amszterdami Szerződés vezette be az EU alapdokumentumaiba, és ezt követôen ez az érték hamar megtalálta az útját az Unió végrehajtási jellegú jogszabályaiba is, mind a munkaügyi, mind pedig az informatikai-kommunikációs területen.

Ezeket a célokat a támogatáspolitika is felkarolta, s az elmúlt évtizedben egyre több uniós pénz áramlott az integrálni kívánt társadalmi célcsoportok foglalkoztatását elốsegítố projektekbe és olyan beruházásokba, amelyek munkahelyeket, iskolákat, valamint közlekedési és infokommunikációs infrastrukturális létesítményeket tettek mindenki számára hozzáférhetôvé. Az Unió kutatási-fejlesztési keretprogramjai kiemelt jelleggel támogatják a digitális tartalmak hozzáférhetôségére vonatkozó, valamint a veszélyeztetett személyek önálló életvitelének lehetôvé tételére irányuló múszaki és egészségügyi kutatásokat. Ilyen módon például számos olyan, ember-gép kapcsolatot lehetôvé tevô innováció jutott el a sorozatgyártásig, amelyek a hallás- és látáskárosultak számára teszik hozzáférhetôvé a szövegeket. Az EU kiemelten támogatja a távápolási és távgyógyászati eljárások kidolgozását, valamint a fogyatékosok és az idôsek biztonságát fokozó kutatásokat is.

Az Amerikai Egyesült Államokban 1978 óta állami intézet (National Institute on Disability and Rehabilitation Research, NIDRR) foglalkozik a fogyatékos személyek életét megkönnyítố kutatásokkal. Kutatási programja kiterjed a célcsoportok társadalmi integrációjára, munkavégzésére, gyógyítására, rehabilitációjára, önálló életvitelére, valamint építészeti, közlekedési és információs hozzáférhetôségi problémáinak megoldására is.

A szekció negyedik elóadása egy speciális oktatási modellt mutatott be, olyan sikeres kísérletként, amely az internetet is felhasználva középiskolai képzést nyújt felnôtt tanulók, köztük számos roma diák számára is. ${ }^{4}$

Az ún. digitális középiskola közpénzekból támogatott kezdeményezés, amely Borsod-Abaúj-Zemplén és Nógrád megyékben a már létezó iskolák, regionális képzốintézmények és közösségi internet-hozzáférési pontok intézményi bázisán ingyenes, decentralizált, jogilag elismert középiskolai oktatást nyújt, fóként hátrányos helyzetû személyek részére. A projektet múködtető Apertus Közalapítvány módszertani központot hozott létre, amely egy virtuális iskolai portálon keresztül terjeszti akkreditált

\footnotetext{
${ }^{3}$ Pcople with disabilitics in the Information Society. Szerzó: Dr. Lovászy László, Szociális és Munkaügyi Minisztérium.

${ }^{4}$ Assessing wcb-based models of secondary adult education. Szerzók: Benda Klára és Simon Dávid, Apcrtus Közalapítvány.
} 
tananyagát. Emellett a diákok a lakóhelyeikhez közeli pontokon tantermi oktatásban és fogadóórákon is részt vehetnek.

A minőségbiztosítással is támogatott szolgáltatásban az elmúlt három év során mintegy félezer hallgató részesült. A projekt idóközi értékelése kimutatta, hogy hatására a térségben csökkent a hagyományos középiskolák magas lemorzsolódási aránya, a rendszer terjesztette a digitális ismereteket, csökkentette a roma közösségek izolációját, és hozzájárult a résztvevók pozitív etnikai identitástudatának fejlesztéséhez. A fenti intézményhálózaton alapuló rendszert 2007-ben kiterjesztik a szakmai képzésre is.

A szekció ötödik elóadása egy speciális élethelyzetû csoport, az ún. „informális gondozók" (informal carers) igényeivel és e csoport digitális technológiákkal történő támogatásának a lehetôségeivel foglalkozott. Az informális gondozók olyan személyek, akik idôs családtagjaik ápolása miatt hátrányokkal szembesülnek a munkaerôpiacon. ${ }^{5}$ A svájci kutatóhelyen kidolgozott koncepció szintén az „eInclusion@EU” projekt részét alkotja.

Felmérések sora igazolja, hogy az informális gondozókat marginalizálódás és munkahelyi hátrányok fenyegetik. Az érintett lakossági csoport létszáma egyrészt azért fog növekedni, mert Európa uralkodó demográfiai trendje a népesség elöregedése, másrészt pedig azért, mert elórejelzések szerint az idôsek otthoni ápolására irányuló igények nem csökkennek. Európában a SHARE felmérés kimutatta, hogy míg a kontinens északi részén az intézményesített családtámogatás elterjedtebb és több az egyedül éló idôs ember, addig a délebbre fekvô és a posztszocialista országokban jobban elterjedt a nemzedékek együttélése, alacsonyabbak az idôs korosztályok foglalkoztatási arányai és itt viszonylag többen foglalkoznak a családjukban élố idôsek gondozásával.

A célcsoport digitális technikákkal történô támogatásának határt szab, hogy a legtöbb informális gondozó személy idôsebb, munkahellyel nem rendelkezó vagy részmunkaidóben dogozó, alacsony jövedelmú nô, viszonylag alacsony szintû infokommunikációs ismeretekkel. A munkahellyel is rendelkezố informális ápolók gyakran szenvednek krónikus fáradtságtól, jellemzően elszigeteltek, társadalmi elismertségük alacsony, és csak ritkán dolgozhatnak rugalmas munkaidóben.

A legtöbb európai országban elérhetô valamilyen támogatás az informális gondozók számára:

- Információk, tanácsadás, képzés, érzelmi támogatás, önsegélyező csoportok

- Gyakorlati segítség: étkezés, üdültetés, szállítás, ápolószolgálat

- Pénzügyi támogatás: adómentesség, jövedelemtámogatás, fizetett szolgáltatások

- Érdekképviselet

- Tanácsadás a munkahellyel rendelkezó informális gondozók számára.

A digitális technikák az alábbi módokon segíthetik az informális gondozókat:

- Információk szolgáltatása a számukra szükséges erőforrásokról és támogatási lehetốségekról

- Speciális élethelyzetüket megkönnyítő képzési lehetôségek

5 The ICT-Contribution to Occupational Opportunities and Work-Life-Balance of Informal Carers for Older People. Szerzố: Michal Arend, econcept AG, Zürich, Svájc. 
- Távérzékelési, távgondozási, távgyógyítási erőforrások

- Az idős személyek önálló otthoni életvitelét megkönnyítô technikák (independent living technologies, ambient assistive technologies, smart home technologies).

Európában az informális gondozók támogatása és az erre vonatkozó kutatás az Egyesült Királyságban, Írországban, Hollandiában és a skandináv országokban a legfejlettebb. A volt szocialista országokban az informális gondozókra vonatkozó támogatáspolitika kibontakozását a gazdasági jellegú hátráltató tényezók mellett a civil társadalom alacsonyabb fejlettsége és az együttmúködési kultúra hiányosságai is akadályozzák.

A szekció hatodik elóadása egy szociálpszichológiai gondolatkísérleten alapuló koncepciót vázolt fel. A prezentáció azt vizsgálta, hogy milyen távoktatási megoldások alkalmasak arra, hogy csökkentsék a roma származású diákok hátrányait, valamint az elôítéletes gondolkodás káros következményeit. ${ }^{6}$

Az etnikai jellegú előítéletek az iskolákban mind a tanárok elvárásait, mind a roma származású diákok önbizalmát kedvezốtlenül befolyásolják. Ha a tanárok a roma diákoktól öntudatlanul is gyengébb teljesítményt várnak el, ez önmegvalósító jóslattá válik, és ez a mechanizmus ördögi körként múködve rögzíti a többségi és a roma diákok teljesítményei közötti eltéréseket. Ezáltal az iskola - ahelyett, hogy csökkentené a társadalmi különbségeket - hozzájárul a szegregáció fennmaradásához.

A távoktatási rendszerek virtuális tantermei azonban lehetôvé teszik akár azt is, hogy a hallgatók saját identitásukat eltitkolva vegyenek részt az oktatás bizonyos fázisaiban. Így megszervezhetố, hogy a tanárok ne szembesüljenek diákjaik etnikai hovatartozásával. Feltehetố, hogy ilyen körülmények között a roma diákok egy része bátrabban kibontakoztathatná képességeit, és esetükben az előítéletesség ördögi köre megszakítható lenne.

${ }^{6}$ Concept of a pilot study to prevent Roma pupils' handicap of school segregation by the use of IT solutions. Szerzô: Síklaki István, ELTE Szociális Kapcsolatok Intézete. 